УДК 113:2-172

\title{
Universe, Incarnation and Humanity: \\ Theology of Thomas Torrance \\ and Modern Cosmology
}

\author{
Alexei V. Nesteruk* \\ University of Portsmouth, UK \\ Lion Gate Building, Portsmouth, PO1 3HF
}

Received 29.11.2015, received in revised form 18.12.2015, accepted 12.01.2016

In this paper we give a philosophical analysis of the spatial paradox of incarnation in theology of the famous XXth century Scottish theologian Thomas Torrance. The paradox is interpreted in the context of modern cosmology, in particular in relation to a basic cosmological principle of uniformity of space in the universe. As a step beyond Torrance's theology the paper analyses the paradox of the incarnation for the elucidation of the sense of the human condition and, in particular, the concept of person as the center of disclosure and manifestation of the universe.

Keywords: cosmology, creation, humanity, incarnation, knowability, person, space, theology, universe.

DOI: 10.17516/1997-1370-2016-9-2-438-469.

Research area: philosophy.

\section{Introduction}

In 1969 Thomas Torrance published his famous book "Space, Time and Incarnation" (Torrance, 1969) where he drew attention of theologians, philosophers and scientists to the fact that if Christian theology is to have a real impact on the state of knowledge and mind of humanity, there must be addressed a serious problem of how to reconcile the Christian teaching of the presence of God in the world with those views on the structure of the universe which follow from modern science. One must admit that the impact of this book on modern studies in science and theology is minimal. Apart from some generic references to this book and complete ignoring of two associated papers (Torrance 1974, 1995), one cannot find any serious development of the problems formulated there, and it is the most sad thing that Torrance's frame of thought hardly to be understood and accepted by moderns participants of he dialogue between science and theology because of Torrance's explicit theological commitment, unpopular among scholars who follow the so called "bottom-up" pattern of this dialogue. It is because of their explicit theological commitment that Torrance's ideas become very close to the heart of the Eastern Orthodox thinkers working in the field of the dialogue who confess their theological commitment as an intrinsic belief-based approach to reality of the world and

(C) Siberian Federal University. All rights reserved

* Corresponding author E-mail address: alexei.nesteruk@port.ac.uk 
of humanity. Thomas Torrance knew well Greek Patristics and, in his personal contacts with the author, gave an indication that he, in many aspects of his perception of Christianity, was orthodox with a capital "O". When one realizes that Torrance was in correspondence with Fr. Georges Florovsky, one does not wonder why, when one reads the first part of his "Space, Time and Incarnation", as well as abovementioned papers on concepts of space in Early Greek thought and Christian theology, one detects the dimensions of a "neo-Patristic" synthesis advocated by Fr. Georges ${ }^{1}$. Florovsky insisted that to study the Fathers of the Church was not to read and cite the relevant quotations. One needs to "acquire the mind of the Fathers" in what concerns their vision of reality, both the Divine and worldly². When one reads Torrance's works on space, time and the Incarnation one learns how to think about God and the world not in mundane forms of thought and speech, but in terms of consciousness of the Divine reason itself, the reason which was transmitted to the Patristic saints through whom we, contemporary humans, can have access to methods and ways of seeing God's presence in the world. In this sense Torrance's writings on the problem of the Incarnation in what concerns its spatial representation give an example of a neo-Patristic thinking which is an important contribution the Orthodox contribution in the dialogue with science.

The most intriguing issue is the meaning of the dogma of the Incarnation of the Son-Logos of God in fully human Jesus Christ as related not only to the interaction between God and humanity, but, in fact to the interaction of God with the whole universe through the Incarnation. In other words, Torrance posed a question on that which in modern theological thought can be termed as "deep Incarnation". According to the idea of "deep incarnation", "the incarnation of God in Christ can be understood as a radical or "deep" incarnation, that is, an incarnation into the very tissue of biological existence, and system of nature"3. From this perspective the Divine Logos has assumed not merely humanity, the whole malleable matrix of materiality by uniting himself with the very basic physical stuff. The flesh that is assumed in Jesus is not only that particularisation of the universe substance in the enhypostasized body of Christ, but also the entire realm of humanity in its connection with all ecological sphere on this planet, its soil and ultimately cosmic matter including its attributes which characterise this matter as existent. Jesus Christ was "not of this world" (John 17:17), that is the world in the sate of human sin, but he conjoined fully with the material world in which he was "at home" (John 1:11).

Contemporary cosmology teaches us that whatever forms of visible matter in the universe, including human bodies, originate in stardust. There remain two realms of cosmic stuff which seem to be not directly consubstantial to this stardust and hence humanity, the famous dark matter and dark energy. Both visible an invisible universe contributes, according to General Relativity to the global structure of space and time and to that which cosmology describes in terms of evolution from the non-originary origin, the Big Bang. Thus, in spite of a heterogeneous nature of the material content of the universe, this universe is ultimately united in itself through its contingency upon the otherworldly principle of existence, namely the life and love of Triune God. From this one could infer that the whole humanity of the humans implies their ultimate dependence on the structural and substantial features of that same universe, which was created by the Logos and through the Logos. What was also understood by theologians, is that humanity was brought into existence together with the Divine promise for salvation and eternal life with God. And the mechanism of the Incarnation was 
foreseen by God as that force which was to fulfil his promise. The promise was not only of bringing humanity to the restoration of the lost unity with God, but also of transfiguring the whole creation by relieving it from the consequences of the Fall. In this sense the coming of Christ through the Incarnation would be the healing of all creation in all its scales and levels. This is the reason why, in accordance of the famous Gregory the Theologian's Christological assertion that "For that which he has not assumed he has not healed, but that which is united to his Godhead is also saved"4, one can conjecture that by descending from the Father, the Son-Logos assumed all features and structures of the created universe.

It was Thomas Torrance, who more than forty years ago anticipated Christology along the lines similar to a "deep incarnation" idea, when he related the whole spatial structure of the universe (which, according to the modern anthropic cosmological inference is responsible for the necessary conditions of the human existence and thus for the possibility of embodiment) to the Incarnation. Here Torrance went to the core of the created world by linking the creation and the Incarnation in a sophisticated dialectics of contingency and necessity, introducing into theological discourse a question of a double order in creation: on the one hand, its contingency, originating in creatio ex nihilo through the unconditional Love of God with respect to the world, and, on the other hand, in its "necessary" Divine order, following from the Incarnation of the Logos as foreseen before all ages, as a mechanism of the union between God and humanity. To assume all aspects of creation is to assume its expression in terms of space and time. Theologically, to assume space and time implied to heal them. But this means that the assumption of space-time parameters of the human existence in the Incarnation always presupposed that those properties of space and time that are due to the
Fall ${ }^{5}$ can be redeemed and overcome in Christ himself. Thus by being in space he was always beyond it in that "nowhere" from "where" the unity of "all in all" of the extended physical space has been preserved.

The assumption of spatio-temporal forms of the universe through the Incarnation of the Logos of God "in flesh" gives to all Christological discussions two dimensions: on the one hand here is the problem of knowability of God: since the created world is permeated by the Incarnation which has been foreseen before creation of the world, there must be signs of the Divine in the world, not only through the fact that the world has its common otherness in the Divine, but through the fact that the world was prepared to accommodate the coming of $\mathrm{Christ}^{6}$. Correspondingly, the relationship between the Father and the Son is implanted in the structure of the world and is recapitulated in the Incarnation of the Son in flesh. Thus to know God means to comprehend the fact of his existence through the world, but retaining in this comprehension a transcendent element not compromising God's otherness to the world. This is related to the "spatial" element in the FatherSon relationship. The physical forms of space and time which were assumed by the incarnate Logos manifest not the actual relationship between God and fully human Jesus, but those forms of comprehensibility of the Divine which were set up by God in order to know him. A simple example is the extended nature of time and space in the postlapserian universe: extension provides the differentiation of the human identity of Christ as its separability from other human beings, as well as human beings from each other. However, the same space is topologically uniform so that human beings can form community as that principle which sustains the universe as Christ's Body. Space has particular characteristics, for example its dimension: this dimension is crucial for the sustenance of biological life in general and 
thus for the possibility of the Logos to assume human flesh. The transcendent indications (paradeigmata) implanted in immanent forms of space, in modern scientific language, account for those undisclosed sufficient conditions responsible for the existence of intelligible life and hence the articulated image of the universe. These conditions, unlike the necessary ones formulated in the anthropic arguments, remain a deep mystery, philosophically related to the perennial issue of contingent facticity of the world. It is the dogma of the Incarnation, as a theological argument, points to the underlying theological reason for the sufficient conditions for the structures of space and time to be exactly as they are.

\section{Spatial Representations in Theology}

Theology has to operate with ideas and concepts which pertain to the created world in order to express the relationship between God and the world. When Christian theology asserts creation of the world by God out of nothing and that there is no necessary link between the essence of God and the essence of the world, that is the world is contingent upon the transcendent creator, theology needs to explicate this doctrine as a certain relationship ${ }^{7}$ between the world and God. As was articulated by T. Torrance with the reference to the Fathers, this relationship cannot receive any spatial or geometrical representation related to the created world even for the demonstrative purposes. A various language is used in order to explicate this relationship appealing to such wording as creation of the world by the Will of God, Creation through Wisdom etc. Maximus the Confessor used the language of the little logoi, through which a certain "link" between things and God was established. Another language of Divine energies is employed in order to express the presence of God in the world. Still the problem is that sometimes all these metaphysical notions are thought of in the physical attitude as a certain causality between the realm of the uncreated and created. The question is: what will be the most efficient language for the Christian panentheism ${ }^{8}$, which would avoid any psychologically connoted spatial and temporal representation of the relationship between the world and God? This could be a language which would replace space-time as objective references of the God-world relationship, and transform it into the conditions of knowledge of $\operatorname{God}^{9}$. Thus there is no space-time extension "between" the world and God, but space-time of the created world becomes the condition of knowing God. Expressed philosophically there must be a change in attitude to creation of the world by God: if, in the natural attitude ${ }^{10}$ this creation is positioned as something external with respect to consciousness which attempts to constitute it, the sought change in the attitude will amount to a procedure of "disconnection" or "bracketing" which transposes the naively experienced world as creation into the intentional field of the created world-for-me. But the world-for-me cannot be the goal of a theological enquiry if behind the disconnection from and bracketing of the world, this world will not appear as the world-for-God. In this sense to bracket the world theologically is neither to deny its reality nor to change its reality in any way. Rather it is to effect a change in one's way of regarding the world, a change that turns one's glance from the sheer given object to the object as one takes it remembering that the very taking of it is possible only through the Godgiven ability to discern the world. The reality of the world is now asserted in the perspective of one's interpretation of the world as real not in itself but real in the perspective of its being created by God. Within the natural attitude the world is attended in the phenomenality of objects. In the phenomenological attitude the 
world is attended as that which has meaning and that which is intended through one's Godgiven capacity to see this world as a medium and condition for realising one's existence and existence of the world. The reality of the world is bracketed only in the sense that one attends to that which presents itself to this one immediately, that is through the fact of life. Whether this is really real in the sense of objects is not a point here, the world is attended as the object of one's intentional acts manifesting life as the Godgiven existence. The created world continues to be physically real in the same sense as real the enquiring subject. The point here is a change of the interest, a change of mind (metanoia), where the noetic pole becomes more important: the question is about one's awareness of the world as well as the sense of being in this world. Thus "the" world in the physical sense is replaced by "one's" or "my" world, not in a solipsistic sense, but only in the sense that "one's" or "mine" indicates an intentional realm constituted by those acts of seeing, hearing, remembering, imagining etc. which are permeated by the Divine image in the comprehending consciousness. The world as creation is then seen as if this image of the world would be that of the Divine Logos through whom and by whom the world was made subsistent in the Divine reason accessible to humanity.

Patristic theology provides a historical example to such a phenomenological approach to creation. Indeed a similar idea and corresponding language, resembling in a way the language of phenomenology, was developed by Leontius of Byzantium. Leontius appeals to that which in modern terms can be described as hypostatic inherence. The latter phrase refers theologically to the Greek words enhypostatic or enhypostasis, which were introduced into heology by Leontius in the context of Christological discussions of 6-7c AD, and whose meaning (appropriate for the purposes of our research) according to "A Patristic
Greek Lexicon" can be described as: "being, existing in an hypostasis or Person", "subsistent in, inherent". Florovsky refers to the terms used by Leontius by saying that enhypostasis points towards something which is not self-contingent, buthas its being in the other and is not contemplated as it is in itself. Enhypostasis is the reality in the other hypostasis ${ }^{11}$. The existence in the hypostasis of the other does not mean a transferral of the hypostasis of a carrier of this hypostasis towards that which is enhypostasized. An inorganic object, which is articulated by consciousness, by existing in the hypostasis of a human being does not acquire personal features of this being. It is merely personified and appears to humans not as that which is in itself, but as that which is perceived and disclosed by a human person. It in this sense, when one talks about the world as contingent creation, whose existence is not selfsufficient, but is sustained through relationship to God, one, in fact, asserts, that the world is "enhypostasized" by God because God is person, whereas the world, as creation, does not even possess a created hypostasis (human beings have created hypostases) $)^{12}$. The term "enhypostasized" is meant to describe a relationship between the world and God. Its remarkable meaning consists in that it expresses this relationship in such a way, that there is no substantial, physical link between God and the world whatsoever. Despite God's transcendence to the world, he is present in the world in a characteristic way, that is enhypostatically through his intent with respect to the world. In different words, the meaning of the phrase that the world is enhypostasized in God, can be treated as that God is present in the world hypostatically in his substantial absence.

The understanding of the relationship between God and the world in terms of enhypostasisation relieves the acuteness of spatial relations between God and the world understood in a manner of extension or distance. Such a 
relationship does not exist because the world is co-present or "stands before" God as that person who made the world, so that there is no extension and distance. This means in turn that it would be incorrect to speak that God "contains" the universe (as it is sometimes done in discussions of panentheism $)^{13}$. However speaking of such a co-presence and standing before, there a certain theological anthropological stance is assumed because the recognition of the person of God as that centre in whose hypostasis the world exists is possible only by the hypostatic creatures, that is human beings made in the image of God. This anthropological stance, explicated through the dogma of the Incarnation, will reduce the arbitrariness of creation (because of the "preceeding" nothing) to some certainty, related to the structure of human persons and the Divine promise for their salvation and eternal life.

In the representation of the world as enhypostasized in the Divine Logos, where the problem with the expression of the relationship between God and the world in terms of any physical connotations is removed, there remains a problem of the specific facticity of space pertaining to the created world, as that transcendental delimiter which makes possible to point to God. This facticity manifests a particular result or the outcome of the enhypostasisation. One may clarify what is meant by this. The universe is contemplated as a contimuum of objects belonging to a common space, whose structure is determined by matter content. The physical parameters of this continuum have specific values: modern cosmology teaches us that the physical universe is old (13.7 billion years) and huge (its potentially visible size corresponds to $10^{28} \mathrm{~cm}$ ), and that its geometry corresponds to the fact of the universe fast acceleration. Humanity lives in the periphery of a mediocre galaxy among billions and billions of other galaxies, in a mediocre stellar system with the contingent number of planets at one of which exists life. It is because of the spatial and temporal incommensurability between the universe and human embodied creatures that there is no sense of talking about the cosmographic centrality of the planet Earth. However, there are specific cosmic conditions which must necessarily satisfy for human beings to be exist in their biological form. These conditions tell us not only that we live in a planet with a very special location, but that we live during a particular temporal era in the overall universe's development. This era is characterised by two major factors: the availability of the physical material (stardust) to form human bodies, and particular large-scale parameters of expansion of the universe, including the tiny balance between the major physical constituents of the universe, which allows us to contemplate and observe the visible universe in such a state in order to draw conclusion on its evolution and origin in the remote past ${ }^{14}$. Thus, in spite of a mediocre position in a vast expanding space, we live in a special era of time which is responsible not only for our physical shape but also for our ability to learn about the universe. One can generalise thus by saying that cosmologically all contingent parameters of the visible universe form the basis for the necessary conditions of existence of conscious life in it. However, the sufficient conditions of life's presence in the universe are not addressed by any arguments, including the anthropic ones. Hence there remains a question: why the world was created by God out of nothing in such a peculiar way in order to have us, that is those who praise God through relating the universe to Him? Rephrased formally, what is the underlying foundation for those sufficient conditions for humanity to exist in the image of God?

The unaccountability of the facticity of human existence in the universe in cosmological terms (that is the impossibility to state the 
sufficient conditions) entails another question: could the enhypostasization of the created universe by the Logos have a radically different form, which, however, could sustain the Divine plan for salvation of humanity and transfiguration of the world? It is here that theology points to the fact that the facticity of the contingent structure of space and time contains some features which point to the unique link between humanity and God without which one could not know God and be in communion with him. This facticity is related to the Incarnation of the Logos of God in Jesus Christ. It is the Incarnation that brings an element of necessity in contingent creation: God contemplated the creation of the world in the perspective of the mystery of Christ, that is the Incarnation of the Logos of $\mathrm{God}^{15}$. Seen post-factum, the Incarnation required a human body, the body of Jesus, as well as the body of his Mother, ever Virgin Mary. The existence of a body is related to the specific necessary physical and biological conditions, and it is understood in cosmology that the whole structure of the observable universe, its spatial and temporal scales are pivotal for that. Correspondingly here is the next question: does the free creation of the world out of love by the Divine counsel presuppose an element of necessity related to the Incarnation of the Logos which was foreseen before the creation of the world and which is related to the recapitulation of humanity in Christ ? $^{16}$ If our response to this question is positive then the structure of space and time becomes related to the Incarnation and reflects a sort of a theological necessity inherent in creation.

One can conjecture that the structure of the natural world has a direct relation to God's providential activity in the world in order to fulfil his plan. This implies that for the Incarnation to take place on Earth, in the visible universe, this universe must possess some features that the making of man in God's image as well as the incarnation of God in human flesh would be possible. This links the creation of the universe and its structure to the phenomenon of man, and the Incarnation articulates this link, making the whole sense of this link rather hypostatic, that is being grounded in the will and love of the personal God, who transfers the image of His personality to human beings who in turn can articulate the universe as being amazingly fashioned in order to sustain life. The cosmological anthropic principle which links the structure of the universe to the conditions of biological existence can then receive its theological generalisation as that principle which links the structure of spacetime and matter of the entire universe with the possibility of the Incarnation. Apart from the physical and biological conditions for existence of living beings this extension touches upon the sense of humanity related to its being the centre of disclosure and manifestation of the universe from within the universe, that is its further enhypostasisation (as articulation) through knowledge ${ }^{17}$. The Divine image requires not only human body, but the archetype of the hypostasis of Christ. To have knowledge of the universe as a whole humanity must have been endowed with that ability of the fully human Jesus to experience the universe as "all in all" by being Christ the Logos who is fully divine and through whom and by whom the universe is created and sustained. Correspondingly the abovementioned extension of the anthropic principle transforms into a theological principle of creation of man in the image of God: the universe must have been created as having the conditions for creation of man in the image of God, the conditions which must have been recapitulated in the Incarnation. However, as humanity is not just the purpose of creation and can be understood only in the context of the promise of God for its salvation (Nesteruk 2003, p. 230). 
The Incarnation reveals itself as a particular mode of refinement of that which is associated with the enhypostasisation of the universe by the Divine Logos. Thus the conditions for the possibility of the Incarnation are encoded in the facticity of the world which is enhypostasized by the Logos, who confirmed this through the Incarnation. And it is this facticity that predetermines the possibility of appearance of humanity as that vessel or that medium in which the Incarnation will be possible, as well as that personal medium through which God will realise the world's communion with himself. One can conjecture in this case that if the Incarnation was foreseen by God before all ages, then the precondition for humanity to appear in the universe must have been contained in the "act" of creation. Then one can further conjecture that the world has been enhypostasised through free creation out of love but with a certain intent. Then one can think that the structure of the material world, despite its contingent character has a direct relationship to the providential action of God in the world in order to fulfil its promise for salvation. For the Incarnation to take place in the visible universe and the Divine promise for salvation to be fulfilled, this universe must have possessed from the very beginning some qualities which would allow the appearance of humanity in the Divine image and kenotic descent of God in flesh toward humanity.

The fact that the providential action of God in the world, in order to fulfil its promise for salvation through the incarnation cascades towards some conditions for the physical structure of creation, can be explicated by commenting on Maximus the Confessor's discussion of the possibility to know God. Maximus affirms that the only possible approach to knowledge of God is through contemplating the effect of the preserving and providential power of God. Here is the quotation:
"It is in terms of no principle or concept or even reality that the divine has relation and communion with the things that are, but it is completely and in every way transcendent, and only grasped from his preserving and foreseeing everything..." 18

There are two important words in this quotation: "preserving" and "foreseeing". These words characterise Divine activity within creation. To preserve means to preserve created things, that is to "conserve" them in their identity from decay to which all creation is subjected; then to take care of these things through sustaining their integrity supporting them to be able to receive God and to respond to his invitation to be in communion with him. "Preserving" could mean the conservation, sustenance of the species, or a particular kind of created objects. This implies that there are no arbitrary transformations among objects; they follow a certain logic of self-identity which ultimately makes every created object unique as individually enhypostasized by the Logos. But the identity of a created object as unique and separate from others implies, from the point of view of the created order, two things: their identity in space, that is their corporeal separatedness, and their identity in time as the possibility of stability and knowability of this particular created existence, as its endurance in the background of the overall contingency of creation ${ }^{19}$. In other words, one can conclude that the divine care with respect to objects and hypostatic beings presupposes existence of these beings as separated and distinct subjects of the Divine care and promise for salvation. By narrowing the discussion to humanity, in particular the humanity of Christ, it becomes even more obvious that the understanding of the Church, as the body of Christ, as catholicity and multi-hypostatic consubstantiality ${ }^{20}$, implies a principle of differentiation of hypostases, that is human persons, which is the differentiation in 
space. This is necessary for the incarnation the Logos to take human nature and to be different and distinct from other human beings. The incarnate Logos-Christ recapitulated human nature in general, but still the incarnation took place in a concrete and specific man - Jesus, who was different from others. It is in this sense that the principle of differentiation of humanity onto many human individuals assumes space as a created medium for differentiation (diaphora) among human beings (not division (diairesis) and separation).

Since the differentiation of humanity still presupposes their unity as related to the same Father, the accommodating space must avoid disintegration of hypostases. Thus the unity of space is of the same quality as the unity of many hypostatic beings: it comes from the Logos and is determined by him. It is exactly from this that the catholicity of humanity of Christ (as conciliarity) receives its justification: catholicity is the unity of people and hence the unity of their shared space; it is not only humanity's consubstantiality, but their con-spatiality as belonging to the same encompassing space which is a form of relationship with $\operatorname{God}^{21}$. The same can be said about time in light of the idea of pleroma of humanity ${ }^{22}$. Correspondingly space and time appear to be those forms of mediation between creatures and God, which make it possible to realise the Divine promise for salvation implanted in the creation. If so, then, by applying the logic of physics of the created one can refine further what kind of space and time it must be.

The "preserving" of physical objects can easily be interpreted as conservation of their physical qualities, related, for example, to energy (mass), momentum (velocity), angular momentum (spin). It is known that conservation laws and the existence of corresponding integrals of motion is the consequence of space-time symmetries. Homogeneity (uniformity) of time entails energy conservation. It is because of this uniformity that the identity of objects as stability in time is possible ${ }^{23}$. Uniformity of space entails momentum (velocity) conservation which makes it possible to separate objects from the forces which acts upon them. Physical cosmology asserts the evolution of the universe in time, but the temporal scale of changes in this universe is so huge (with respect to the human life on Earth) that one can assume that time is homogeneous. The uniformity of space is confirmed by indirect observations and serves as a major epistemological presumption in cosmology (cosmological principle) on the knowability of the univers $\mathrm{e}^{24}$. If, coming back to the quotation from Maximus, "preserving and foresseing" is addressed to the modes of humanity's knowledge of God, then one can go further by explicating this "preserving" first of all as preserving of human beings themselves. But preserving implies, first of all, existence. This existence is conditioned by the necessary conditions following from physics and biology. Thus preserving in this case means the support of fundamental physical constants which are responsible for the stability of material structures, like planets and atoms, which make it possible the corporeal existence of human beings and, theologically, the Incarnation to happen. For example, the dimension of space $\mathrm{d}=3$ is necessary for the planetary and atomic orbits to be stable and thus "preserving" those structures which are necessary for life ${ }^{25}$. This type of a link between the large-scale structure of the universe and the fact of existence of life that appears in cosmology in rubrics of the anthropic inference can be employed in order to demonstrate that the "preserving" of the large scale-structure of the created universe and hence human life in it can be used a pointer (paradeigmata) towards detecting the presence of the Divine in the universe. Most importantly in the context of Torrance's discussion is that the facticity of space and time can be used as a witnesses to the very special relationship between 
God and the world, ultimately explicating the sense of that the world is enhypostasised by God: the world is hypostatically in the Person of God. If this "is" for God is the bringing the world inside the sphere of Divine interiority, in order to make the world of its own and to bring it in communion with Himself, for the created humanity this "is" is the all-encompassing wholeness of the world as its spatial, geometrical whole, which, in spite of its extended properties seen from within the world, is perceived as the manifestation of the Divine relationship to the whole world as devoid of any extension and distance. One can say that the universe as a whole is theologically homogeneous, that is "theogeneous", because God is present at every point of the universe through the fact that all parts of the universe are equally enhypostasised by him, so that there is no extension and distance between God and the universe. In this sense if sometimes the universe is presented graphically as a geometrically extended shape embedded in a sort of pre-existent continuum, for the Logos of God this universe is an instant or an event, in which all distances and ages are encapsulated in the archetypically present "all in all". This implies further that space (and time) reveal themselves as those particular modalities of the world which explicate this "all in all" in the conditions after the Fall, that is as extended and distant in itself. Since the created world is corporeal the extended space perceived by human beings can be treated as that corporeal form of the enhypostasisation and hence of communion with the Divine which itself is "preserved" by God (and which is the source of further "preserving" through a purposeful articulation of the universe by human beings).

\section{Incarnation}

\section{and its space paradox}

Now it is worth to take a more close look at the space paradox which arises from theology of the Incarnation and which was articulated by
T. Torrance. On the one hand, Jesus Christ, being in his nature fully a man, lived in the world and was located in a body in a particular place and time of the Earth's history. On the other hand, being fully God, he did not leave his 'place' on the right hand side of the Father, and thus, being God, was present not only in Palestine two thousand years ago, but was always present in all locations and ages of the universe created by him. We have here a non-trivial temporal and spatial relationship between the finite "track" of Jesus Christ in empirical space and time and the whole encapsulated history of the universe as the unity of "all in all" of spaces and times sustained by the Logos-Christ.

Historically it was Origen who first reflected on the extraordinary position of Christ, being man and God, in the universe conceived of in terms of space:

"Though the God of the whole universe descends in his own power with Jesus to live the life of men, and the Word which 'was in the beginning with God and was himself God' comes to us; yet he does not leave his home and desert his state." ${ }^{26}$

Origen stressed here the point that God, who is the creator and governor of the whole universe, by becoming incarnate in the flesh in Jesus Christ, did not cease to be, as God, the provider of existence and intelligibility for every thing at every place in the universe. Being incarnate in the flesh, that is being a man among men, Christ as God was still ruling the whole universe and holding together the entire creation. By creating the universe and giving it meaning so that it could receive the his Son in the flesh, God has prepared a place for himself $\mathrm{f}^{27}$, but in such a way, that while descending into the created world in a particular place and time he still holds the entire creation together (through enhypostasising it), being hypostatically present in all possible 'places' of the universe. Thus the Incarnation recapitulates 
not only human nature but the whole creation in the totality of its spatial and temporal spans.

By being incarnate at one point of space and at the same time not leaving his 'place' as transcendent Creator, and by holding together the wholeness of space, God demonstrates that his relationship to space is not a spatial relation. Origen asserts this explicitly:

"The power and divinity of God comes to dwell among men through the man whom God wills to chose and in whom he finds room without changing from one place to another or leaving his former place empty and filling another. Even supposing that we do say that he leaves one place and fills another, we would not mean this in any spatial sense." ${ }^{28}$

Athanasius of Alexandria expressed the unity of the divine and human in Christ appealing to the analogy of space in terms similar to those used by Origen:

"Then the incorporeal and incorruptible and immaterial Word of God entered our world. In one sense, indeed, he was not far from it before, for no part of creation had ever been without him who, while ever abiding in union with the Father, yet fills all things that are." ${ }^{29}$

Athanasius argues in this passage that in spite of the fact that the Son-Word of God descended to Earth in order to live with men, he did not become closer to us by doing so, for he is always in everything in the universe, which was made by him. 'Space' is a predicate of the Word of God; it is determined by his agency and is to be understood according to his nature. This means that the 'spatial relationship' between the Father and the Son is in no way analogous to the spatial relations among creaturely things. Human nature in Christ always operated within the reality of empirical space and historical time, whereas his divine nature was always beyond the empirical and intelligible aeons in the uncreated realm from where Christ the Logos of God coordinates the empirical space in which he dwelt in the body with the rest of the created universe. The Christ-event, being thus a manifestation of the spatio-temporal relationship between God and the physical universe expressed as an open-ended interaction between God and man, recapitulates the humankind-event in the universe, making the latter an expression of the interaction between man and God and of a contingent happening in the eternity of God.

One can use a different analogy in order to illustrate this point. Indeed, extended space and time are perceived by human beings from within creation and can be treated as "internal" forms of the relation of the universe with the transcendent Divine (the "extended" corresponds here to the old Patristic term diastema). The Greek term diastema meant in Classical Greek geometry the distance between two points, in music the interval between two notes. In the theological context the term diastema was used by Gregory of Nyssa in order to charactarise the created world as extended in space and in time. He used this term in a negative sense in order to predicate about God by affirming that there is no diastema (that is of extension of a spatio-temporal kind) in the being of God. It is more important for us to point out a different usage of the term diastema, which Gregory applied in order to describe the theological distinction between God and the world. This distinction contains an asymmetrical dialectics in the relationship between God and the world: on the one hand there is the diastema between God and the world, which is unbridgeable from within the world, on the other hand God knows the world, which He created. The diastema in this case can be represented by a asymmetrical, one-way extension in relationship between God and the world: indeed, there is a basic diastema if one attempts to cross the gulf between the world and God from within the world, on the other hand there is no extension, that is there is no diastema 
in the Divine hypostatic holding of the world. Then the question arises as to how the extended internal space-time of the universe maintained in relationship with the divine 'environment' (that is its non-extended "external" form) in which it "embedded" in the sense of being created? Here an analogy with the hypostatic union of the two natures in Christ can be used. Indeed, it is because of the hypostatic union between the divine and the natural (human) in Christ that one can argue by analogy that the interplay between the space and time of the universe (their internal form) and its uncreated ground (its external form), is also upheld hypostatically by God in the course of the "economy" of the Incarnation when the link between the humanity of Christ (in space of the created world) and his divinity as the Logos (who is beyond space and yet holds all space together) was established. This leads us to the assertion that the universe in its spatiotemporal extension manifests its Christologically evidenced hypostatic inherence in the Logos.

This theological understanding of the extended space-time structure of the universe as a manifestation of the relationship between God and the world, God and humanity, can cause discomfort among modern scientists who can easily conceive that space and time are relational upon the matter content of the universe (this is the main idea of General Relativity). However, to conceive of the whole spatial structure of the universe as expressing the relationality upon the other-worldly Divine agency, would be very challenging for them, in particular, it would be difficult to conceive the meaning of that Patristic phrasing that the incarnate Word of God, that is the person of Jesus Christ was not far from the world before the incarnation, for no part of created universe had ever been without him who, while ever abiding in union with the Father, yet fills all things that are and that he does not leave his home and desert his state. It seems here that any logic is broken if Christ is approached only as an incarnate, that is a corporeal being whose appearance in the universe took place at the very late stage of its evolution. However, that which is asserted in theology is not a physical statement but the assertion of that relationship between the universe and its otherworldy foundation which was previously described by using the language of hypostatic inherence. Inherence implies a different type of presence which escapes properties of spatial and temporal extension. Interestingly enough, modern cosmology, in spite of the fact that it deals with the universe extended in space and time, characteristically implies, by its theory of the Big Bang, that whatever is physically seen as extended in space and time, in fact, evolved from an originary state beyond the extended space and time. In this sense all extended places in the universe that we observe in the sky point towards this original state with no space and time and thus we are, on this planet, in the same "place" as we would have been at the Big Bang. If now we explicate this simple mathematical fact theologically, one can realise that the words of Athanasius that Christ as the Logos was not far from the world before the incarnation can receive a literal interpretation. If, for simplicity, we adopt a model of evolution of the universe from the Big Bang, it can receive a pictorial representation through the following diagram (Fig. 1).

This diagram attempts to express the unity of space and time as being generated from their non-originary origination "event" depicted by a circle of the Big Bang at the centre of the diagram. The diagram consists of series of expanding concentric circles which aim to represent spatial sections of space-time. The circles expand from the initial zero point which symbolizes the origin of the universe. The radii correspond to the world lines of particular objects (clusters of galaxies, for example) which originate at the singularity 


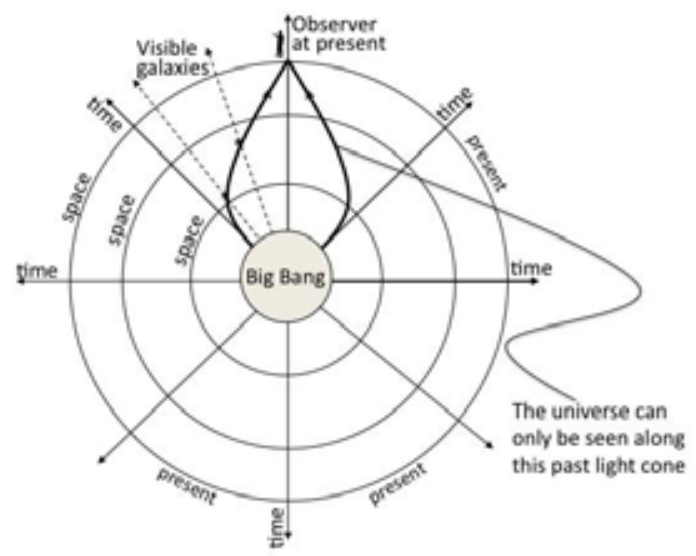

Fig. 1. The unity of the universe as generated from the Big Bang

(corresponding to zero linear scale) and diverge in all directions. The fact that the spatial sections (that is, concentric circles) in this diagram are compact must not be interpreted as if we deal with a topologically closed universe. If these imaginable circles are associated with some structural units of the universe (galaxies or their clusters), their expansion reflects only the process of the mutual recession of galaxies. The major conceptual difficulty with the interpretation of this diagram is to conceive the meaning of the point of origin of the world lines. One must not treat this diagram as if it depicts the actual process of expansion in pre-existent space or time. Actually this origin is not in space and in time, so that its depiction as a point in the plane of the page is a metaphor. However, the diagram as a whole can be treated as representing the global structure of space and time in the natural attitude, that is as if they existed objectively and independently of the human observer who appeared in the universe at its late stage. The distinction between past, present and future has a purely symbolic nature (associated with the radius of a circle, or progression of the world line) as divisions in abstract "objective" time. What is important in this diagram is that the spatial position of the human observer depicted at the top of the diagram is absolutely the same as if it would be at the very beginning of the universe in the Big Bang. It corresponds to a constant radius commencing at the Big Bang and going straight to the observer. The fact that the observer is situated exactly at the same place where the Big Bang took place is also confirmed by the curvilinear past light-cone (looking as an onion shape), which has it origin in the Big Bang: indeed whatever we observe in the sky is coming to us from the Big Bang. Why these last two points are important for our discussion of the Incarnation? The answer is simple: if we assume that the Big Bang is the point of origination of the universe as we see it and which we interpret as related to creation, then one can expect that the Divine Logos was "present" at this point as the creator. But, as we have seen, this point of creation is now exactly where humanity is situated: thus the Logos never ever was "absent" from the "point" of creation and its extension in space, including our present location. Correspondingly if the Incarnation happens at the same point of space where we are, then one can say that this is the same point where the Logos was present from the beginning. Then the phrasing of Athanasius that Christ as the Logos was not far from the world, that is the human world on this planet, before the incarnation indeed receives a literal 
interpretation: the Incarnation has happened at the same location in space where the Logos was "present" from the beginning of the world. Thus cosmology involuntarily reproduces in a geometrical language a simple theological truth that the universe as being created is related through all its ages and locations to the LogosCreator who became incarnate at the same location where he was present from the beginning. Interestingly enough, the issue of the contingency of the event of the Incarnation in space looses in this picture any sense: the Incarnation happens in such a location in the universe which remains the centre of its expansion and being geometrically and physically equivalent to all other points of the universe (cosmological principle).

It is trivial to say that since the universe was enhypostasised by the Logos the Logos is hypostatically present everywhere in the universe. However the Incarnation makes a further reification to this saying. Since Christ receives human flesh he turns out to be in a double position: as the person-Logos he is present everywhere, however as being fully human Jesus is subjected to the physical causality. This means that he has access to that part of the universe which contains the physical conditions for corporeality and is subject to restrictions on the knowability of the universe following it. Christ's presence everywhere manifests the lack of diastema in the God-the world direction, whereas his subjection to the worldly causality manifests exactly the opposite, namely the distema between humanity and God in terms of extended space. Theologically, the diastatic perception of space which pertains to humanity corresponds to the state after the Fall. Correspondingly the extended universe perceived by humanity can be treated as originating in the human incapacity to actualise the archetypical vision of the universe as "all in all". Christ, being human, but devoid of any affections by the Fall, experiences the universe in the conditions of space-time extension, but this extension, having nothing to do with humanity's sins is not in any tension with his hypostatic perception of the universe as a whole. Christ reconciles the extension in the universe with its integrated enhypostasised wholeness. If in Christ the overcoming of the tension between the perception of the universe as extended and instant has an ontological character, because of the hypostatic union of two natures, in human beings, who have archetype of Christ, this happens only epistemologically. This means the following: since humanity is physically prevented from communion with the whole universe, it develops its intelligible image whose possibility proceeds from the Divine image in humanity itself. If in Jesus Christ the intelligible image of the universe does not share the phenomenality of objects, because this universe is inseparable from the Logos-Christ consciousness, in human beings, the intelligible image of the universe does appear in the phenomenality of objects, because human beings are not involved in that enhypostasisation of the universe which is associated with its creation. They can enhypostasise the universe on a different level through knowledge, but still the universe will remain an object of humanity's intentions for finding its accomplished mental representation. The split in human comprehension of the universe as extended physical reality which contains human beings corporeally and as an integrated intelligible image of the universe as a whole which stands in front of humanity in its articulated form, creates a paradox in the human condition similar to the paradox of the Incarnation.

\section{Paradox}

\section{of Human Subjectivity}

We will now explicate the paradox associated with the ambivalence of the human position in the universe. If one tries to demonstrate the whole 
grandeur of the world for example in terms of a typical size, putting in a diagram microobjects (atoms, molecules, DNAs etc.) together with mega-objects like planets, stars, galaxies, clusters of galaxies and even the whole universe, then human beings find themselves in somewhat strange situation because the inhabited planet Earth, which has a radius of $10^{9} \mathrm{~cm}$, occupies only a tiny portion of space equal to $10^{-57}$ of the volume of the visible universe; also the spatial scale of human body (post natal adult state) $10^{2} \mathrm{~cm}$ is negligible with the size of the visible universe. In a similar way, the universe had a beginning 13.7 billion years ago, and then developed to its present state, so that the humanoid type of life appeared on the planet Earth approximately 1 million years ago, it is not difficult to realize that the phenomenon of humanity came into existence at a very late stage in the history of the universe, so that the universe was devoid of human life and hence devoid of its self-expression during the most part of its "history". If the human presence in the universe is judged from the point of view of its spatial and temporal dimension, human beings, turn out to be a contingent and insignificant part of the universe.

The paradox which is present here arises when one realises that the very representation of the universe as a whole and the diagram which positions all objects in the universe against humanly organized spatial grid, are the products of human intellectual activity. The paradox is obvious: the insignificant embodied human agencies in the vast universe articulate the entire universe from a point-like position in space and time. Humanity actualises in knowledge the totality of the universe as its intentional correlate and this manifests a fundamentally non-local essence of the human presence, being a quality and a mode of being which transcends the finitude of its corporeality, as well as all particular objects and laws associated with it.
One can see that if cosmology positions humanity in the vast universe, then humanity represents a particular type of "objects", passively dependent on the universe. The so called "anthropic inference" in cosmology refines assertions about humanity's position in the universe asserting consubstantiality of the universe and humanity in quantitative terms pertaining to specific embodiment ${ }^{30}$. In a way, this is a trivial observation that affirms self-consistency of the human knowledge of the universe with the physical conditions of corporeality which make this knowledge possible. The anthropic inference deals with the necessary conditions for physical and biological existence of humanity and does not cover the realm of its sufficient conditions, related to humanity's intellectual capacity ${ }^{31}$. In this sense the famous characteristic of humanity as "microcosm" is fundamentally inadequate ${ }^{32}$. The mystery of the sufficient conditions remains obscure in the same sense as the inability to account for the contingent facticity of all, including consciousness itself. The natural attitude of consciousness which effectively attempts to explain the origin of this consciousness as the epiphenomenon of the physical and biological fails to recognise that it attempts to explain itself from itself (this was understood in phenomenology). This fallacious logical circle originates in the fact that physics and biology operate in the framework of the already given consciousness but this very consciousness never becomes their subject matter (Gurwitsch 1974, p. 133). It is because science cannot accommodate the dimension of personhood, it has to abandon the reference to embodiment at all and to treat consciousness as a medium of access which is hypostatically uniform and thus nonobservable. It is because of such an oblivion that the human presence becomes irrelevant to the universe whereas sciences themselves become obscure (Gurwitsch 1966, pp. 399-400). As it was 
put by Merleau-Ponty: "Scientific points of view, according to which my existence is a moment of the world's are always both naïve and at the same time dishonest, because they take for granted, without explicitly mentioning, it, the other point of view, namely that of consciousness, through which from the outset of a world forms itself round me and begins to exist for me" (MerleauPonty 1962, p. ix).

The ambivalence in assessing of humanity's position and role in the universe can be expressed in terms of a famous philosophical paradox asserting that whilebeing in the universe, humanity is not of the universe that is, in a certain sense, it transcends the universe by "holding" it through humanity's grasp. Any cosmological discourse has to reconcile the locality and contingency of cosmic position of humanity with its abilities to transcend this locality and encompass in theory the universe as a whole. Consciousness manifests its "irreducible ambiguity" (Kersten 1972, p. 527) which follows from the fact that this consciousness is in the world, as well as of the world insofar as it is consciousness of the world (Gurwitsch 2010, p. 160). There is a split of intentionalities which are at work in human subjectivity: one is directed to the universe and treats it in the phenomenality of objects, that is as a thing among other things; and another one treats the primary and unavoidable link with the universe (events of communion) as a basis for all other explanations of the universe, as that center of manifestation and disclosure through which the universe becomes palpable and intelligible. Any naturalistic attempt to suppress or subvert the essential ambiguity of consciousness distorts the sense of the created universe.

The abovementioned paradox was coined by E. Husserl as "the paradox of human subjectivity being a subject for the world and at the same time being an object in the world" (Husserl 1970, p. 179). However, it was known since ancient times, and Kant, for example, expressed it in his Critique of Practical Reason as the difference in appreciation of "the starry heavens above and the moral law within" (Kant 1959, p. 260). The paradox received numerous formulations and interpretations (see (Carr 1999)) and we would like to make a few generalising and clarifying references. M. Merleau-Ponty, rephrased the same paradox in the context of the tension between two tendencies of describing the human condition in classical philosophy which, according to him, must be overcome on the ways of existentialism. (Merleau-Ponty 1982, pp. 7172). E. Fromm, departing from a psychological dimension, gave to this paradox a status of "existential dichotomy" arising from the fact that, according to him, man emerged in being as "anomaly" and "the freak" of the universe, whose being in a state of constant and unavoidable disequilibrium, anxiety, dissatisfaction and restlessness, which follow from being part of nature and transcending it (Fromm 1967, p. 40). Similarly to Fromm, R. Ingarden describes the existential dichotomy as a very special and doubly-complexioned of man's feeling of being, on the one hand, quite alien to everything that happens in nature independently of him, so that he sees himself deprived by it of any kindly help and almost loses trust in fate; on the other hand, "in his pure and autonomous essence he feels himself to be something that stands out above nature, something that is so much more dignified than purely physical processes or what transpires in animals, that he cannot feel in solidarity with nature and live fully happily by being united with it in its domain" (Ingarden 1983, pp. 17-18). According to Fromm and Ingarden's insights humanity, when it narrows it perception of the place in the universe to the status of a thing among other things, dooms itself to depression and anxiety of its own insignificance in the vast cosmos because life is enslaved and controlled 
by it. Contrary to this the cosmos acquires some inward meaning if humanity sees itself as the centre of its disclosure and manifestation. Then the universe receives intrinsic human qualities thus being united to humanity: the question then is not of being positioned in the universe, but that of living here and now in communion with the universe. But this communion mean much more than sheer consubstantiality. It means that a human being can "transcend" the universe while retaining its immanence with the universe.

The paradox of human subjectivity was understood long before by Patristic theologians ${ }^{33}$ such as Gregory the Naziansus ${ }^{34}$ and Maximus the Confessor $^{35}$. Some Russian Orthodox thinkers of the $20^{\text {th }}$ century also contributed to the recapitulation of a theological sense of the paradox. According to N. Berdyaev: “... Man as personality is not part of nature, he has within him the image of God. There is nature in man, but he is not nature. Man is a microcosm and therefore he is not part of the cosmos" (Berdyaev 1944, pp. 94-95). Man is not only an object in this world, first of all he is subject which cannot be deduced from an object. Taken with this the relation of man to cosmos is defined by its being microcosm; he enfolds cosmos and history. Man cannot be a part of something, he is the whole. Through the spiritual in him, man is not subordinated to nature and independent of it although natural forces can kill him (Pascal 1959, p. 78). P. Florensky wrote in the same vein: "Nature and man are both infinite. And it is because of being infinite, that they are commensurable and can be parts of each other... Man is in the world, but man is complex to the same extent as the world. The world is in man, but the world is also complex as man" (Florensky 1994, p. 186). S. Bulgakov contributed to the same stream of thought: "On the one hand, man is potential all, the potential centre of the antropocosmos, which, although, not yet realised but is being realised, on the other hand man is the product of this world, of the empirical" (Bugakov 1993, p. 160).

\section{The Paradox of Human Subjectivity and the Paradox of the Incarnation}

If the paradox of human subjectivity reflects the intrinsic feature of the human condition in general, then, according to the Chalcedonian definition, Christ himself, by being fully human, that is through His belonging to the created world, must have experienced and exhibited the presence of the above paradox. By his human nature Christ was contained in the universe, while by his Divine nature he was not contained by anything in the universe, because he it was him who contained the universe through its hypostatic inherence in the Logos of God. Two natures were united in the hypostasis of the Logos, and this made visible to humanity that the Divine can be united to the human and created, thus manifesting the mutual co-inherence of two natures and thus mutual co-inherence of two different senses of space as containing Jesus and as being contained by Christ. The power of upholding the entire universe by Logos-Christ while being on this planet, which can be seen as the explication of this co-inherence in spatial terms as related to the geography of the Holy history and the entire universe, can be interpreted as an anticipatory sign (type) of what humanity, made in the image of God, is endowed with. By the power of comprehension human beings can hold the entire universe in integrity of their intersubjectivity, suspending its apparent spatial extension and differentiation, and thus relating the universe to its transcendent Creator. The Incarnation of the Logos in Jesus Christ thus revealed to human beings that the mystery of their paradoxical existence in the world is rooted in their special origin in God, who himself through his Incarnation provides humanity with the only possible reference for comprehending and overcoming this paradox. 
In the same way as the presence of Christ in a particular location in space and time in the universe did not prevent him, as the Logos, from being present everywhere in the universe hypostatically inherent in Him, the presence of humanity in a particular location in the universe does not preclude this humanity from being present everywhere through "inherence" of the universe, in the hypostasis of humanity, whose archetype is Christ himself. One should understand, however, that the universe as an intentional correlate of human subjectivity, is not an "ontological" mode of being in the same sense as the hypostatic inherence of the universe in the Person of the Logos. The universe is created by the Logos as a personal relation of the Logos with human persons and that is why it is ontologically contingent upon and derivative from the Logos. The mode of the universe's existence in its sheer facticity represents the Logos' desire to have the universe in a particular shape in order that the Logos himself could indwell in the universe ${ }^{36}$.

One can conjecture that the paradox of human subjectivity in the world points towards a fundamental twofoldness of the human embodied existence, that is their physical finitude in space and time, as well as the potentially unlimited capacity of knowing the world, which both originate in the Logos of God, who created the world as extended in space and time and who, while creating the world, transferred some of its intrinsic rationality to human beings making them the bearers of the Divine image.

When we affirm that the world (or the universe) can be understood as the enhypostasis of the Logos of God, we say that the world exists in the hypostasis of the Logos, so that it is the personality of the Logos which forms the foundation of the world. However the world as such is not hypostatic. There is one particular domain in the world, namely the community of human beings, which can be interpreted as hypostatic. Human beings are enhypostasized by the Logos as hypostatic creatures, so that their own hypostases are not self-sufficient. All other objects, such as physical particles, fields and their complex combinations are not hypostatic at all, so that their existence can only be manifested in the hypostasis of the other, namely in the hypostasis of human beings and, ultimately, in the hypostasis of the Logos.

If we now try to comprehend, in these terms, the Incarnation of the Logos of God, the second person of the Holy Trinity, in Jesus Christ, and say that the Logos was incarnate in flesh we mean, in fact, something like this: the Logos enhypostasized himself in the human body by preserving his own hypostasis. If we compare the Incarnation of Christ with embodiments of other human beings, we can formulate the difference: the self-enhypostasization of the Logos in Jesus Christ was a deliberate action of the Logos with respect to himself, the enhypostasization of other human persons is a deliberate action of the Logos with respect to created beings. The act of enhypostasization of created human beings can then be treated as the intentional immanence of the Logos towards establishing the relationship with human persons. This assumes that there must be some commensurability between the Logos and human beings which is usually denoted as the divine image.

But the enhypostasisation of other human beings by the Logos is not only the act of bringing the relational aspects of existence to human beings with respect to the Logos himself, but also the implanting of some intrinsic relationality among human beings which is perceived as intersubjectivity, as an ability to share knowledge and emotions, to know each other through love. It is here that the Logos imitates among human beings that all-permeating love which he experiences himself in the community of the Holy Trinity. It is interesting to realize here that the 
very possibility for all different existents which are brought into hypostatic being by the power of the Logos, to overcome their solitude and enter the sphere of the shared existence, is founded in the Logos himself. It is through the very existence of the intersubjective field of consciousness that the fact of the implicit presence of the common existential source for all human persons becomes accessible to the attentive mind. This common ground, which is linked to the presence of the light of Christ in all of us, as well as the awareness that there is the immediate surrounding world among all of us which seems to be the same in spite of the differences among persons, points out in a characteristic way that there is some fundamental non-locality in human apprehension of the world, the non-locality as accessibility to different scales and levels of reality including heir shared accumulated past. It is this non-locality of the human condition in the universe which expresses the paradox of human subjectivity in the world and which forms the mystery of intersubjectivity not only as communicability among persons, but also as an access to the intelligible imprint of human history. The Incarnation of the Logos in flesh at one particular point of the universe, and his simultaneous presence everywhere in the universe provides us with the archetype of how the all-penetrating human subjectivity can affirm itself from a particular position in the Cosmos on the planet Earth. It is through their opposition to the whole of creation, through the particularisation as the radical otherness, that existents receive their existing, that is they receive their unrepeatable experience of being. The contraction of the existing by a potentially existent creature is exactly what theology describes as "special making of man", as a manifestation of our relationship with the Logos. To know the Logos means to transcend our solitude, to transcend our being existent in potentiality and to contract our existing as existing in the Logos. It is through our inherence in the Logos who assumed the humanity that human beings share an ability to articulate the world as inherent in the Logos.

\section{Paradox of Space in the Incarnation as the Explication of Space of Personal Relatedness to God: beyond Thomas Torrance}

Now we are going to link the paradox of human subjectivity to the paradox of space in the Incarnation. The paradox of human subjectivity can be formulated in terms of space, that is in terms of humanity's topological position in the universe. The formulation in terms of space is achieved through a metaphor of the container and of the contained: on the one hand by its physical and biological parameters humanity is contained in the universe, on the other hand the universe itself is "contained" by human subjectivity as its intentional correlate (that is enhypostatically). In this formulation the ontological centrality of humanity is contraposed to its cosmographic mediocrity (cosmological principle). The distinction between two worlds is accentuated here: the world which is affirmed by cosmology as existing whole and scientifically thematised in terms of elements and essences, and another world, associated with the immediate life of consciousness, the so called life-world ${ }^{37}$, the medium of indwelling into which every human being is brought into existence. This life-world, being "here and now" for every particular being is linked to the planet Earth and thus is geocentric. Earth is ontologically central in a spiritual sense ${ }^{38}$, that is in the sense of "wherefrom" manifestations and disclosure of the universe do originate. In spite of the fact that astronomy and cosmology deal with Earth as an object and ascribe to it a movement in space, both cosmology and astronomy were produced by human beings on Earth, and it was here, on this planet, that scientific thought developed the definitions of motion, 
rest, space understood in a general objective sense. Cosmologists' statements concerning the indifferent position of Earth in cosmic space (cosmological principle) receive their meaning from experiences acquired here, on the planet Earth. The here which is the place of this initial experience is not therefore a place in space, since it is itself a place of origin of a notion of space (this point has its theological reference in Christ the Logos as the source of all space by himself not being in space). In this sense the cosmological principle, as a philosophical hypothesis, enters into contradiction with the singular and unique "here" which is radically incomparable with any "there" thus predetermining the non-homogeneous topology of any ideation about space at large. The nontrivial nature of this last comment follows from a phenomenological stance on space not as the pre-existent objective out there (articulated through subject's passive contemplation of it), but in terms of subject's comportment "in" it (this constitutes a difference with Kant's view of space and time as a priori forms of sensibility). This, so called, attuned space becomes an initial instant and a medium of disclosure of that "objective" space through relation to which this subject is constituted as corporeal existence in space. However this relationship is manifest of a paradox similar to that of the container and of the contained put in an interrogative form: how can one grasp the relationship of a particular being (subject) as if it "in" space when this being is essentially constituted by being 'over against', and hence beyond space? (Ströker 1965, p. 15). In the context of the Incarnation, its spatial ingredient must be interpreted from the side of the Son of God's active and controlling occupation of bodily existence and place. This is related not only to the place of physical embodiment, but also to the "place" of the whole universe. Place (as space-time extension of the universe) is a predicate of the Occupant in the sense that it is predetermind by his agency. This purely theological thought receives some connotations with General Relativity's stance on space-time structure of the universe, as being relational, that is being a predicate of its "occupant", that is the material content. This analogy between theology and physics has a very limited value for the relationality of physical space-time has a strictly created nature, whereas when space-time of the whole universe is predicated in terms of the Divine activity, it has, so to speak, a transcendent meaning where the generation of space as relational upon Divine activity and nature has the sense of creation of this space out of nothing in view of the forthcoming Incarnation of the SonLogos of God in Jesus Christ.

What is obvious, however is that the constitution of space, first of all of the attuned space is intertwined with and not detachable from the fundamental aspect of human embodiment or corporeity, where embodiment or corporeity manifest itself neither as a system of some biological processes, nor as simply a body animated by the soul, nor even a simple unity of both of them. It is a living being in relation to other beings and to the world, in whom this relation is announced and articulated in a way of its sense-reaction and its comportment, or its action in situation. In this sense the constitution of space in all its varieties (from attuned space of immediate indwelling to mathematical space of the universe) represents the modes of explication of embodiment or corporeity through which human beings interact with the world. Thus the lived body entails a sort of lived space which bears the character of self-givenness "in the flesh". In other words the stance on the initial point of any discourse in corporeity and associated spatiality implies a kind of knowledge as presence "in person" or "in the flesh" as a mode of givenness of an object in its standing in front of the functioning corporeity. 
In cosmology, by articulating the entirety of the universe human beings remain corporeal, so that their corporeity as relationship to all things contains in its facticity the very premise of being physically incommensurable and at the same time hypostatically commensurable to the totality of the universe which humanity attempts to reveal. The attitude to this totality is two-fold: on the one hand humanity attunes to it through belonging to it; on the other hand, humanity positions itself as if it were beyond the universe, as if it "looked" at this universe as an object and depict the latter as something being present over against "the flesh" and in person. However, since humanity cannot abandon its position of corporeal existence in situation on the planet Earth, all cosmological models contain the elements of embodiment even in those cases when they predicate the universe in trans-human or even non-human (the early universe) terms. In other words, the commensurability with the universe is not of space, but originates in space ${ }^{39}$.

One may now, in order to articulate the sense of the paradox of space in the Incarnation, suspend the natural attitude with respect to space and to consider a genesis of spatiality as a certain form of relation to the world formulated from within the developing subjectivity. For example, if one looks at child's appearance into this world in the act of birth, from the external point of view his life depends on the world's conditions and in this sense is open to the world's invitation to exist. The main existential factor in this initial mysterious unseparatedness between a child and the world, which naturally creates sensual discomfort and inherent anxiety and which must be removed in the presence of the mother who by nursing this child loves him and smiles to him, brings this child in the relationship of love. It is this early sensual consciousness of the other, the mother, through love inaugurates in a child the sense of space. Space appears as a mode of relationship, in which, on the one hand, a loving human being manifests itself as a pre-conscious ecstatic reference, whereas on the other hand the same human person is caught in consciousness as the other supplemented by the spatial attributes of this otherness expressed in terms of extended (and measurable) space. This dialectical "standing in front of" and "standing apart from" in personal relation is an existential fact which cannot receive any further foundational justification. Its contingent facticity is an historical event which cannotbe repeated and reproduced in experiments. This is an event of emergence personhood through relationship and thus through "standing apart from" (expressed through local distance and other measurements) that creates a spatial dimension of this relationship. Knowledge of other persons is possible through this "either standing in front of" or "standing apart from" and implies the intuition of space either as inseparable presence or absence. This is related not only to other human beings, but also to knowledge of nature as the reality of the other. One can admire the grandeur of the visible universe by experiencing it either through the personal "opposite" of ecstatic reference (that is as presence) or as the opposite measured through spatial dimensions (that is as absence) wit respect to that which is not the "I". In this dichotomy the presence of the personal ecstatic reference to the other, its fundamental irreducibility from sensual experience and personal consciousness, predetermines the intuition of space as a definite form of experience and subjectivity. Here the "I" that cannot give an account for the facticity of its personal ecstatic reference to the world, is formed by this reference which is projected in consciousness as a form of "standing apart", that is of space. Thus the perception of space can be considered as an apophatic mode of expression of the initial inseparability in relationship between humanity and the world, which follows not only from consubstantiality, butalso from the implanted 
Divine image. Space becomes a vehicle of human involvement in the world through hypostatic differentiated embodiment which makes possible the relationship with world's objects as well as other persons.

The language of communion with the world and other persons implies in a way a phenomenological attitude because the space of personal relationship is unfolded from within events of life. In this attitude the very notion of the outer world originates from within the boundaries of the same personal relationship and thus the making of the world an abstact and independently existing object can originate only from within the condition when the very personal relationship to the world receives a status that of similar to objects. The world as a personal "opposite" of ecstatic reference is perceived in the dialogue between humanity and the world as some other "I" enhypostasised in my "I". The representation of the personal relationship with the world in the phenomenality of objects consists in that the world becomes a passive object of observation and study, from which feelings and the eros of consubstantial communion is removed. The very consubstantiality with the world becomes an abstract notion, which is not experienced through communion. The world becomes an object and the personal space of "standing in front of" the world transforms into a sheer "standing apart from" the world in space as measurable and controlled extent. Space is presented in the phenomenality of objects when the relationship with the world is transferred into the sphere of pure thought which thinks this relationship but does not experience it. Philosophically, this can be expressed a that it is inside thought that the breakdown of the unity between subject and object takes place. It is in the conditions of this breakdown that the representation of space acquires more and more geometrical, measurable character associated with the boundaries of things (as objects), that fill in the universe.

It is exactly this way that cosmology thinks of space, where the measure of this space is determined by its capacity to contain astronomical objects, that is by "density" of these objects as the measure of their standing apart from each other. This measure is determined by the number of light years required to "join" these extended objects in one united cosmic whole. Despite such a vision of the universe in the phenomenality of objects, the experience of placelessness of the universe, that is the experience of the universe through an ecstatic inarticulate personal reference remains irreducible and unavoidable. This "standing in front of" the universe as the personal "opposite" is free from any physical references and its actual physically infinite extent, and thus remains indeterminate in the limits of the logical faculty of scientific thinking rooted in the category of quantity and based in the mundane geometrical intuitions of spatial hierarchy in terms of "closer" and "far", "here" and "elsewhere", "right" and left" etc. In this sense the universe as a term of personal relationship manifests itself in relation of its sheer presence, but such a presence that cannot be described in terms of place. Thus here is a delicate form of presence in absence. It is indicative that the experience of the universe as absent in terms of space and its undisclosed content turns out to be more impressive and apophatically manifesting the whole majesty of the personal ecstatic reference to the universe in comparison with any specific aspect of the universe's presence in details of spatial objects. In both cases, either through experience of belonging to the universe through consubstantiality with it, or through experience of its absence because of the impossibility to circumscribe the universe in forms of thought, this experience determines the space of personal relationship as a certain indeterminantcy of "standing in front" of the 
universe (as non-extended and non-measurable). Space as relationship thus signifies the modality of life, a certain existential aspiration and interest which cannot be dissected into motivating components. Space expresses existential events of movement towards the other as manifestations of the very basic foundations of being of humanity. However, this movement towards the other is not self-evident and indistinguishable in itself. Its revelation is possible and is taking place only in the conditions of awareness of space as a potential threat of "standing apart", that is separation, if that movement towards the other and "standing in front" of the universe cease to function as element of life. Here is a dialectics of space: it is always capable of being transformed from the condition of personal relationship into a soulless form of separation and quantitative measurement if life of a hypostatic embodied subject is stared to be treated as determinism of biological survival, and the universe, instead of being a participant of the relationship, becomes an impersonified background of existing whose contingency not only cannot be comprehended, but, in fact, cannot be even detected.

Modern cosmology can hardly comprehend the sense of non-extended space of personal relationship with the universe not only because it does not consider the universe as enhypostasised in the Person of the Logos and thus disregards all indications of personhood of the creator, but first of all because cosmology treats the universe in terms of presence. Its "elementary" constituents, such as galaxies and their clusters, are treated as present in physical space as if consciousness could shift itself from its home place on Earth and treat these objects in the same phenomenality which pertains to the objects on Earth. Presence here implies "standing apart", as experience of substitution of the home place. The very space of the universe is objectified as extension. Hence the experience of presence is linked to the sense of extension: presence in presence assumes the representation of things or embodied human beings as being extended in space ${ }^{40}$. It is in this sense that when one speaks of humanity as multihypostatic consubstantiality that one uses the idea of presence. Multitude of persons is given in abstraction as extension in space, but the very characteristic of every person as unique existence having its own space of personal relationship is missing here because it is difficult to catch this space in terms of presence.

The difficulty in conscious reflection upon the enhypostasized features of the universe as a whole originates not only in the fact that one cannot physically transcend the universe. Human beings do not consider the universe through their personal relationship to God, they do not experience a dynamic existential relationship with the universe as if this universe would be a person. In other words, the universe is not positioned as the other term of the relationship of love. But love implies gratitude for that it is the universe which can be loved in principle. To love the universe means to thank God for his creation and thus to confess an eucharistic attitude to the universe which is just another way of saying that the universe exhibits Divine presence and it hypostatic inherence in the creator. The intuition of the universe as the created wholeness always functions as that invisible background (present in absence) for the natural attitude and implies such a relationship of "standing before" when all extensional plurality of experience is reduced to null in the event of ecstatic relationship and kenotic aspiration towards the universe's creator ${ }^{41}$. There is a double meaning is hidden in this event: the ecstatic personal relationship with respect to God precedes any consciousness either of his presence or absence in the universe and thus of consciousness of presence or absence of the universe as created totality. Said formally, there is no automatic assurance based 
in the understanding, not only in objective expression of God's presence in the universe, but also in an objective existence of the universe as a whole. The existential reality of God and the world, created by him, are defined through the immediate proximity of the relationship so that the very person and its subjectivity, not being able to verbalise and objectivise this relationship, is constituted by this relationship in "non-objectivised space."

It is this non-extended and non-measurable intimate "opposite" of the personal relationship that constitutes space as relation. The universe as "noema" of the Divine intention "stand before" God without any extension; however this "standing before", as relation, has a tendency of being expressed in the human perception of God as extended space ${ }^{42}$. On the one hand there is no space between God and the world (God abides in the human heart without any spatial connotation); on the other hand, being an embodied creature in the extended universe, human beings experience their relationship with God and his creation in the modality of space. On the one hand man manifests himself in the placeless totality of its own articulating hypostasis (the world is present in absence); on the other hand, as functioning corporeity, he feels himself isolated in the world of dividing but present extension. Here, again a problem formulated above: how can one grasp the relationship of a particular being (subject) as if it "in" space when this being is essentially constituted by being "over against", and hence beyond space?

Our analysis shows that the spatial sense of the relationship between humanity and God is hardly to be amenable to clear stratification. If fact, here one deals with the different form of the paradox of human subjectivity applied to space. There is an ambivalent relation to space on the side of human beings: on the one hand they are carriers of spatial relations, because they explicate their relationship with God as placeless standing before; on the other hand, space as extension constitutes human beings simply because every specific subject is defined in terms of behaviour in space; this subject knows himself in relation to the other, to the world, that is to the extended space which always accompanies human beings in their placeless modality.

Now we come back to the issue of the Incarnation. It is because humanity, being embodied creation, exists in the world in the conditions of the paradox of its own physical finitude and theological infinity, it transfers this paradoxical situation to the event of the Incarnation of the Word-Logos of God in Jesus Christ. Since in the Incarnation of the Logos in Christ human nature is conjoined to the Divine nature, Christ, being fully human does not experience the duality which is explicated in the paradox of subjectivity. Since the hypostasis of the Logos controls the conditions of its own Incarnation, Christ-man does not experience any ambivalence of his placeless being in the plenitude of God and, at "the same time", of his existence in the conditions of the spatial extension of "standing apart from" God in his creation. Since the Logos in the Incarnation does not leave his place on the right hand side of the Father, the placeless presence of God in Christ-man means his omnipresence in the conditions of extended space.

The event of the Incarnation, its scandalous claim, as it was perceived by the Greeks, plunges the human understanding into despair and paradox. This paradox arises in that state of human consciousness which originates in another event of the Biblical history, namely in the Fall, when the sense of "all in all" (Col. 3.11), associated with the inherent communion with God had been lost. Thus the refusal of the natural attitude in contemplation of space, when the extension, as a physical property, becomes 
a non-extended "object" of an intentional gaze in the phenomenological attitude, could be paralleled with consciousness of God himself, for whom the whole world is the event-relationship. The problem of duality of God's presence and absence in space of the world, which is articulated by the special spatial aspects in the dogma of the Incarnation, de facto, explicates the apophaticism in knowledge of God and its antinomial character within the limits of the logical faculty of thinking. Here also the boundaries of transcendence in knowledge of God associated with the rubrics of space are outlined. Transcendence as the overcoming of extended space and division of the objects of the world is related not to getting beyond its external cosmological limits, but to the bringing of space inside the intentional consciousness thus reducing the problem of space to the problem of the foundation of its contingent facticity in this consciousness. Space remains an inherent element of every perception and thought in the natural attitude, being inherent in the Logos who enhypostasizes the world as the unity of "all in all" in the conditions of its spatial extension. It is the pole of the all-unity of space as the extension subjected to bracketing and suspension, that remains to be in the phenomenological attitude an inerasable trace of non-spatial spatiality ${ }^{43}$. The issue of the facticity of space leads inevitably to the problem of the facticity of consciousness itself. The facticity of the human embodied consciousness is exactly accompanied by the paradox which has so long been discussed. Any attempt of overcoming this paradox would correspond to transcendence of the boundaries of the very factual givenness of this paradox and this would entail either exit beyond the embodied consciousness or exit the world order. Since this is not an option for human beings, that is the paradox is unavoidable in the post-lapserian condition, what is left to humanity is to find its ultimate archetype in which the "standing before" and "standing apart" in the relationship between the world and God is overcome by the Divine humanity of Jesus Christ.

\footnotetext{
See a general discussion in (Williams 1993).

2 See discussion of a possible strategy of a neo-Patristic synthesis in the dialogue between theology and science in (Nesteruk 2008, pp. 1-59).

3 The term "deep incarnation" was coined by a Danish theologian Niels Gregersen in his paper (Gregersen 2001). See also (Gregersen 2010).

4 Gregory the Theologian, Letter 101.32 [ET: (Hardy 1954, p. 218)].

5 The idea that the perception of extended space and time of the physical universe corresponds to the postlapserian state not only of humanity, but the universe itself, corresponds to the theologically understood loss of such a communion with God in which the whole universe was given to humanity as "all in all". In some studies was suggested that the very expansion of the universe originating in the Big Bang, which is obviously associated with extensions of space, can be considered as the human perception of the event of the Fall projected onto cosmic scales. See, for example (Rodzyanko 2003) and (Sokolov 2008).

6 Athanasius of Alexandria develops the thought that by becoming human, the Word of God "became visible through His works and revealed Himself as the Word of the Father, the Ruler and King of the whole creation", De incarnatione, 16 [ET: (Athanasius 1998, p. 45)]. Athanasius argues that despite the fact that the Father provided the works of creation as a means by which the maker might be known, this did not prevent men from wallowing in error. De incarnatione, 12, 14 [ET: (Athanasius 1988, p. 39, 42)]. Because of this, the Word of God descended to men in order to "renew the same teaching." However one must admit in the vein of our argument that in order to send the Word for the renewal of God's teaching there must have be the conditions for the very possibility of this related to the fact of existence of men and hence the possibility of the Incarnation.

7 Fr. S. Bulgakov in his (Bulgakov 2002, pp. 221-22) advocated that the adequate description of the relation between the world and God cannot be established on the grounds of mechanical causality, that is that God is the cause of the world. This relation is that of the creator and the created. The creative act of God of creation of the world is rather an ecstatic transcendence of God through creation of the world. Creation manifests itself through relationship between God and humanity. This relationship does not subordinate to the constituting constraints of it manifesting historicity. This relationship, as well as the relationship between God and the world is subordinated only to the promise of God for salvation and eternal life, that is of renewed creation.

8 See on panentheism (Clayton, Peacoke 2004).
} 
9 The Incarnation sets these conditions by proclaiming that the incarnate Son of God is the "place" where the Father is to be known and to be believed, for he is the "place" where God to be found. But "place" here must be interpreted in accordance with nature of God and his activity in revelation and redemption through the Incarnation.

10 The term "natural attitude" introduced in phenomenology by Husserl can be elucidated by a long quote from M. Natanson: "Within the natural attitude I act in a world which is real, a world that existed before I was born and which I think will continue to exist after I die. This world is inhabited not only by me, but also by my fellow men, who are human beings with whom I can and do communicate meaningfully. This world has familiar features which have been systematically 1described through the genetic-causal categories of science. The world of daily life is lived within this natural attitude, and as long as things go along smoothly and reasonably well, there arises no need to call this attitude into question." The reasonability and wellness is related to the situation when the question about the contingent facticity of that which is going on around, including the facticity of the "I" does not arise. Then Natanson continues: "But even if I do occasionally ask whether something is "really real", whether the world is "really" as it appears to be, these questions are still posed in such a way that they are my questions about the natural world in which I live. I do not really scrutinize my natural attitude in any rigorous manner: I merely mark off a bit of it for more careful study" (Natanson 1959, p. 232). Since, as we argue in this paper, the natural attitude is not suitable for the description of the relationship between God and the world, as well, as between the whole creation and humanity, the elucidation of these questions can be done only on the grounds of questioning the very facticity of the natural attitude.

11 See e.g. (Florovsky 1987, pp. 191-203). One should point out that the novelty of the Christian Patristic use of the term "enhypostasisation" originates in the distinction between substance (nature) and hypostasis, which is different to certain extent from what may seem to be similar to the Aristotelean distinction between primary and secondary substances. Leontius of Byzantium articulated this distinction: "Nature, then, that is, essence, could never exist without hypostasis. Yet nature is not hypostasis, because the terms are not convertible; hypostasis is nature, but nature is not hypostasis. For nature admits the principle of existence; hypostasis, that of existence by itself. Nature holds the principle of form; hypostasis points out an individual thing. Nature shows the distinctive mark of a universal; hypostasis divides the particular from the common" (Contra Nestorianos et Eutychianos [PG 86, 1277 D] (quoted in (Relton 1917, p. 78))). See more on the interplay between the Aristotelean philosophy and Leontius' Christology (Daley 1978), in particular pp. 27-39.

12 Rephrasing Athanasius, human beings who are not capable of self-existence are enclosed in place as contingent things and subsist in the Logos of God. But God is self-existent, enclosing and circumscribing all things (enhypostasizing them), and being enclosed and circumscribed by none. He is "in" all things according to his goodness an power since these things all inhere in him, but he is "without" all things according to his proper nature (Cf. De decretis, 11 [PG 25, 441d]); "..in place nothing is far from God [God is present in things], but only in nature are all things far from him [God is absent from things]" (Cf. Contra Arianos, 3.22 [PG 26, 369b]).

13 One sees here a sharp contrast with Newton's view of absolute space as a Divine receptacle.

14 The point that we live in a very special cosmological era when the large sacele universe is accessible to observation and its evolutionary features can be detected, so that one can make the prediction of the Big Bang, is well articulated in literature on cosmology. See, for example, (Krauss 2012, pp. 121-139).

15 Avoiding a long discussion on whether the Incarnation was caused by the Fall, or the opposite, that the hypostatic union of God and man was the eternal fulfillment of the will of God (see (Nellas 1997, pp. 34-42, 94-96)), or a more recent discussion in (Bugur 2008) our position is that since the universe and human beings themselves were enhypostasized by the Logos, so that humanity was capable of making room for its Archetype, that is the incarnate Logos, the creation of the universe out of nothing must have been effected in view of the mystery of Christ and his kind to be an instrument of the Incarnation and perfecting the Divine image (see Maximus the Confessor, Ad Thalassium 60 [PG 90, 621A]).

16 Christianity rearticulated the Biblical idea of the fullness of humanity by referring it to Christ, the Incarnate Logos of God. Irenaeus of Lyons developed the idea that it is in the Incarnation that the fullness of humanity was recapitulated by Christ (Against the Heresies, V:16,2). In the Incarnation in flesh, God recapitulated in Himself that ancient handiwork of His which is man (III: 18,7); He recapitulated in Himself the long history of mankind (III: 13,1). Irenaeus asserts that by taking human flesh, made of the substance of this world, and uniting it to the Divine in Christ, God confirmed that the substance, which He used initially to create man is linked to God's first plan to save man, and the Incarnation fulfils this plan. This implies that for the Incarnation and recapitulation of all human nature in Christ to take place, the substance of the world was chosen by God in His plan of creation of the world and salvation of man, making thus this particular substance as existing in the hypostasis of God, who created it.

17 Prestige in order to illustrate how the apprehending knowledge becomes hypostatic existence refers to Clement of Alexandria (Stromata, 4:22, 136:4), in order to articulate the point that speaking of knowledge, "apprehension extends by means of study into permanent apprehension; and permanent apprehension, by becoming, through continuous fusion, the substance of the knower and perpetual contemplation, remains a living hypostasis. This appears to mean that knowledge becomes so bound up with the being of the knowing subject, as to constitute a permanent entity" (Prestige 1955, p.176).

18 Maximus the Confessor, Scholia on the Divine Names (of Dionysisos the Areopagite) [PG 4. 321 B] [ET: (Yannaras 2005, p. 63), emphasis added].

19 When one speaks about the intelligible world, one can speak about "preservation" of ideas and intelligible entities in general, that is regardless time - it is a kind of "logical conservation", sustenance etc. However being projected onto human life, this conservation of ideas is understood as their constant presence in time in the mind of human being. Time is still present as that background which makes it possible to discriminate temporality as a flux and a-temporality as frozen time. This means that our articulation of eternal ideas assumes the intrinsic temporality of our consciousness. Preservation in this case means the stability of our consciousness, i.e. the conditions such as memory, or even the structure of the internal time-consciousness, which makes it possible to discern patterns and structures in the background of the variety of sense- 
data. Stability of consciousness includes not only memory but also ability to attempt to plan the future as if it has already been in existence. One means here the memory of the future, as the realisation of that teleological ingredient which is present in human consciousness as activity. Thus "preservation" means in this sense some particular pattern of the human subjectivity which makes it possible to contemplate God across the multihypostatic consubstantiality. "Preservation" means the faithfulness of God to humanity and constant presence in it and this is exactly the sustenance of space and time as the conditions of this prolonged presence.

20 See on the link between multi-hypostatic consubstantiality and catholicity (sobornost) a paper (Zenkovsky, 1988).

21 Here is a symbolic analogy with the unity of the Church space (where the Church is understood not only as a temple, but as a whole created universe) in Maximus the Confessor's Mystagogy 2, where he says that a certain 'blessed old man' used to speak " $[\ldots]$ of God's holy Church as a figure and image of the entire world composed of visible and invisible essences because like it, it contains both unity and diversity. For while it is one house in its construction it admits of a certain diversity in the disposition of its plan by being divided into [...] a sanctuary and [...] a nave. Still, it is one in its basic reality without being divided into its parts by reason of the differences between them, but rather by their relationship to the unity it frees these parts from the difference arising from their names. [...] In this way the entire world of beings produced by God in creation is divided into a spiritual world filled with intelligible and incorporeal essences and into this sensible and bodily world which is ingeniously woven together of many forms and natures. This is like another sort of Church not of human construction which is wisely revealed in this church which is humanly made, and it has for its sanctuary the higher world assigned to the powers above, and for its nave the lower world which is reserved to those who share the life of sense." [ET: (Berthold 1985, p. 188)]

22 The intuition of fullness of humanity through ages of time, that is of all generations of humans who ever lived is formulated in the idea of fulfilment of pleroma of humanity, that is of the fullness of the "body" of humanity in Christ. Gregory of Nyssa argues that when the Holy Scripture says "God created man according to His image and likeness", it does mean “...the entire plentitude of humanity was included by God of all, by His power of foreknowledge, as it were in one body... The whole race was spoken of as one man... Our whole nature, then, extending from the first to the last, is, so to say, one image of Him Who is." (Gregory of Nyssa, On the Making of Man, 17. [ET: NPNF, series 2, vol. 5, p. 406, (emphasis added)]. See also (Ladner 1958, p. 82)]. The fact that for its fulfilment pleroma of humanity in its fallen state needs time and generations of procreation, indicates that on the one hand, all human beings (including those who lived before the Incarnation) are created in the image of God; on the other hand if one thinks about the fulfilment of pleroma of humanity as some event in the future, one thinks of the ecclesial catholicity as an eschatological objective of the whole movement of creation towards its transfigured state in God.

23 Whatever mode of understanding related to analogies of experience cosmology uses, it places its subject matter in rubrics of time which, according to Kant, guarantees the unity of experience (Kant 1933, A 177/B 219-220).

24 This point was developed in my papers (Nesteruk 2012[1], 2012[2]).

25 See in this respect (Barrow, Tipler 1988, pp. 258-76).

26 Origen, Contra Celsum, IV [ET: (Bettenson 1969, p. 213) emphasis added].

27 Here it is appropriate to establish a linguistic parallel with G. Marcel's meditations on the sense of the term "receptivity". When we said above that God prepared place for himself this must not be understood as "filling up some empty space with an alien presence, but of having the other person(s) [that is humanity] participate in a certain reality, in a certain plenitude". In this sense to receive humanity means to "to admit someone from the outside to one's own home". To make space for God means to invite persons to participate in the Divine reality (Marcel 2002, pp. 90-91).

28 Origen, Contra Celsum, I.277 [ET: (Chadwick 1953, p. 187)].

29 Athanasius, On the Incarnation, 8 [ET: (Athanasius 1996, p. 33) emphasis added].

30 Anthropic inference deals with the so called fine tuning establishing a balance between the physical constants responsible for the large-scale structure of the universe and conditions of biological existence. The literature on it is vast, so that we refer only to the cited above classical monograph by (Barrow 1988), (Barrow et al. 2008).

31 The sufficient conditions become actual in the present state of technology when humanity effectively can control the factors of life's existence on the planet Earth from the side of so to speak "negative conditions': indeed, humanity is in capacity to exterminate life on Earth so that the future continuation of life depends not only on the natural conditions and possible disasters which can terminate this life, but also on a conscious desire to have this life. This desire belongs to the sphere of the human morality and humanity's vision of its own destiny and that is why is not entirely controlled by the physical factors. (See some discussion in (Nesteruk 2003, pp. 195-208)).

32 The idea of microcosm was strongly criticised in Christian literature because it did not take into account human intellectual abilities to disclose the sense of the universe. According to Gregory of Nyssa, for example, "there is nothing remarkable in Man's being the image and likeness of the universe, for earth passes away and the heavens change...in thinking we exalt human nature by this grandiose name (microcosm, synthesis of the universe) we forget that we are thus favouring it with the qualities of gnats and mice" (quoted in (Clément 2000, p. 34).

33 The detailed discussion of the paradox of human subjectivity in a theological context can be found in (Nesteruk 2008, pp. 175-84).

34 Gregory Naziansus, Oration 45, On Easter, 7 [ET: (Nellas , p. 203)].

35 Maximus the Confessor, Ambigua, Difficulty 41, [PG 91, 1304-1312B] [ET: (Nellas 1997, p. 212)]; Ambigua, 10:26, [PG 91, 1153B] [ET: Philokalia, v. 2, Virtue and Vice, Fifth Century: 71, p. 277].

36 God prepared place for himself as inviting and admitting other human persons to participate in the Divine reality. C.f. footnote 15 .

37 The concept of the "life-world", introduced by Husserl in his last book (Husserl 1970) and has many overtones extensively discussed in phenomenological literature. See, for example (Steinbock 1995). 
38 This point was clearly articulated by V. Lossky: all forms of thought of the other worlds remain no more than mental images, eidetic variations on the level of intelligible forms. These other worlds exhibit the creaturely reality of the spiritual order. The invocation of other worlds does not lead us to the Divine and Christian theology warned against this: "the mysteries of the divine economy are thus unfurled on earth, and that is why the Bible wants to bind us to the earth [that is our universe, $\mathrm{AN}]$.... it forbids us to lose ourselves in cosmic immensities (which our fallen nature cannot grasp anyway, except in their aspect of disintegration), ... it wants to win us from usurpation of fallen angels and bind us to God alone... In our fallness we cannot even place our world amidst these spiritual immensities" (Lossky 1997, p. 64). When theology asserts creation of the world, it implies not only creation of this visible universe, but also creation of other invisible worlds which can have "physical" incarnation, but can also have none. What is important in Lossky's quotation is that the very necessity and value of appealing to these intelligible worlds is doubtful simply because we have nothing to do with them and cannot understand their meaning and purpose in the conditions where the meaning of our own physical world remains obscure.

39 For human beings to achieve the sense of commensurability with the universe one must be in space as a delimiter of their embodiment. Interestingly that this conclusion is similar to a Christian theological stance on space in the context of knowledge of God. It is because the incarnation of the Logos of God took place in rubrics of space and time, that no knowledge of God is possible outside the ways of Christ in space and time. (This was a point of Torrance in his book (Torance 1997)).

40 This thought dates back to Origen who asserted that bodily nature is needed to support the lives and uphold the movements of rational minds; bodies are needed for diversity and individuation in this world (See, for example, De principiis, Book II, 9:6 [ET: On First Principles, (Butterworth 1973, p. 134-35)]).

${ }^{41}$ As an example of this one can point to the Anaphora in the Divine Liturgy, or to the prayer for the whole world of monks living in reclusion and "beyond" the world, and contemplating the whole being from the cell of their solitude.

42 This is typical for all sorts of mythologies which develop a theme of a gradual and spatial relation between gods and the world.

43 It is worth quoting here Gregory of Nyssa who wrote in the context of unknowability of God that "..no created being can go out of itself by rational contemplation. Whatever it sees, it must see itself; and even if it thinks it is seeing beyond itself, it does not in fact possess a nature which can achieve this. And thus in its contemplation of Being it tries to force itself to transcend a spatial representation, but it never achieves it. For in every possible thought, the mind is surely aware of the spatial element which it perceives in addition to the thought content; and the spatial element is, of course, created...." (Gregory of Nyssa, Commentary on Ecclesiates, sermon 7 [PG 44, 730 A] [ET: (Daniélou1981, p. 127)]).

\section{References}

Abbreviations:

PG: ed. J. P. Migne, Patrologia Graeca, 161 vols., (Paris, 1857-66).

NPNF: The Nicene and Post-Nicene Fathers, ed. P. Schaff and H. Wace (Grand Rapids, MI: W. B. Eerdman Publishing Company, 1994-96).

The Philokalia: St. Nikodimos of the Holy Mountain and St. Makarios of Corinth. The Philokalia:

The Complete Text, vol. 2, ed. G. E. H. Palmer, P. Sherrard, and K. Ware (London: Faber, 1986).

\section{Classical and Patristic Writers:}

Athanasius of Alexandria, De decretis 11 [PG 25: 441d].

Athanasius of Alexandria, Contra Arianos 3.22 [PG 26: 369b].

Athanasius of Alexandria, (De incarnatione) [ET: On the Incarnation (Crestwood, N.Y.: St.

Vladimir's Seminary Press, 1998)].

Gregory Naziansus, Oration 45: 7 [ET: (Nellas 1987, p. 203)].

Gregory of Nyssa, On the Making of Man [ET: NPNF, vol. 5, 1994].

Gregory of Nyssa, Commentary on Ecclesiates [PG 44] [ET: (Daniélou, 1981)].

Irenaeus of Lyons Against the Heresies.

Leontius of Byzantium, Contra Nestorianos et Eutychianos [PG 86].

Maximus the Confessor, Ad Thalassium [PG 90].

Maximus the Confessor, Ambigua 10:26 [PG 91: 1153B] [ET: "Various Texts on Theology, the

Divine Economy, and Virtue and Vice, Fifth Century”, 71 (Philokalia, p. 277)].

Maximus the Confessor, Ambigua 41 [PG 91: 1304-1312B] [ET: (Nellas 1987, p. 212)].

$$
-465-
$$


Maximus the Confessor, Mystagogy (The Church Mystagogy) [ET: (Berthold, 1985, pp. 181225)].

Maximus the Confessor, Scholia on the Divine Names (of Dionysisos the Areopagite) [PG 4: 321 B] [ET: (Yannaras 2005, p. 63)].

Origen, Contra Celsum [ET: (Bettenson 1969)].

Origen, Contra Celsum [ET: (Chadwick 1953)].

Origen, De principiis [ET: (Butterworth 1973)].

\section{General Bibliography:}

Balthasar, H. Urs von, Cosmic Liturgy. The Universe according to Maximus the Confessor (San Francisco: Ignatius Press, 2003), pp. 137-42.

Barrow, J. D., Tipler, F. J., The Anthropic Cosmological Principle (New York: Oxford University Press, 1988).

Barrow, J., Morris, S., Freeland, S., Harper, Ch., (Eds.) Fitness of the Cosmos for Life. Biochemistry and Fine-Tuninng (Cambridge: Cambridge University Press, 2008).

Berdyaev, N., Slavery and Freedom (London: Centenary, 1944).

Berthold, G. C., (tr.), Maximus the Confessor. Selected Writings (New York: Paulist Press, 1985).

Bettenson, H., The Early Christian Fathers (Oxford: Oxford University Press 1969).

Bugur, B., "Foreordained from All Eternity: The Mystery of the Incarnation According to some Early Christian and Byzantine Writers", Dumbarton Oaks Papers 62 (2008), pp. 199-215.

Bulgakov, S., Philosophy of Economy (Moscow: Nauka, 1993) (in Russian: С. Н. Булгаков, Философия хозяйства. Соч. в двух томах., т. 1, М.: Наука, 1993).

Bulgakov, S., Bride of the Lamb (Grand Rapids, MI: W. B. Eerdman Publication Co., 2002).

Butterworth, G. W. (tr), Origen, On the First Principles (De principiis) (Gloucester, Mass.: Peter Smith, 1973).

Carr, D., Paradox of Subjectivity (Oxford: Oxford University Press, 1999).

Chadwick, H., (tr), Origen, Contra Celsum (Cambridge: Cambridge University Press 1953).

Clayton, P., Peacoke, A., (Eds.), In Whom We Live and Move and Have Our Being: Reflections on Panentheism in a Scientific Age (Grand Rapids, MI: W. B. Eerdmans Publishing Company, 2004).

Clément, O., Le Christ Terre des Vivants. Essais Théologiques. Spiritualite Orientale, n. 17 (Bégrolles-en-Mauges: Abbaye de Bellfontaine, 1976).

Clément, O., On Human Being. A Spiritual Anthropology (London: New City Press, 2000).

Daley, B. E., Leontius of Byzantium: A Critical Edition of His Works, with Prolegomena, Doctorate dissertation (Oxford University, 1978).

Daniélou, J., (selected and introduced by) From Glory to Glory. Texts from Gregory of Nyssa's Mystical Writings (New York: St. Vladimir's Seminary Press, 1981).

Florensky, P., "Macrocosm and microcosm", in Apology of the Cosmos (St. Petersburg, Russian Christian Humanitarian Institute, 1994), pp. 184-97 (in Russian: П. Флоренский, Макрокосм и микрокосм//Оправдание космоса, СПб.: РХГИ (ВГК), 1994, с. 184-97).

Florovsky, G., "Cur Deus Homo? The Motive of the Incarnation", Collected Works, Vol. 3: Creation and Redemption (Belmont: Nordland Publishing Company, 1976), pp. 163-70. 
Florovsky, G., The Byzantine Fathers of the Six to Eight Century (Vaduz: Büchevertriebsanstalt, 1987).

Fromm, E., Man for Himself (London: Routledge and Kegan Paul, Ltd., 1967).

Gregersen, N., "The Cross of Christ in and Evolutionary World", Dialog: A Journal of Theology 40, n. 3 (2001), pp. 192-207.

Gregersen, N., "Deep Incarnation: Why Evolutionary Continuity Matters in Christology", Toronto Journal of Theology 26, no. 2 (2010), pp. 173-87.

Gurwitsch, A., Phenomenology and the Theory of Science (Evanston: Northwestern University Press, 1974).

Gurwitsch, A., Studies in Phenomenology and Psychology (Evanston: Northwestern University Press, 1966).

Gurwitsch, A., The Field of Consciousness (Dordrecht, Springer, 2010).

Hardy, E. R., (ed.), Christology of the Later Fathers (The Library of Christian Classics), (Westminster Press, Philadelphia, 1954).

Husserl, E., The Crisis of European Sciences and Transcendental Phenomenology (Evanston: Northwestern University Press, 1970).

Ingarden, R., Man and Value (Washington, D.C.: Catholic University of America Press, 1983).

Kant, I. Critique of Pure Reason, tr. N. K. Smith (London: Macmillan, 1933).

Kant, I., Critique of Practical Reason (London: Longmans, 1959).

Kersten, "The Constancy Hypothesis in the Social Sciences". In L. Embree (Ed.) Life-World and Consciousness. Essays for Aron Gurwitsch (Evanston, Northwestern University Press, 1972), pp. 520-532.

Krauss, L. M., A Universe from Nothing (New York, Free Press, 2012).

Ladner, G. B., "The Philosophical Anthropology of Saint Gregory of Nyssa", Dumbarton Oaks Papres 12 (1958), pp. 59-94.

Lossky, V., Orthodox Theology (Crestwood: St. Vladimir's Seminary Press, 1997).

Marcel, G., Creative Fidelity (New York, Fordham University Press, 2002).

Merleau-Ponty, M., Phenomenology of Perception (London: Routledge, 1962).

Merleau-Ponty, M., Sense et Non-Sense (Evanston: Norhwestern University Press, 1982).

Natanson, M., "Being-in-Realty", Philosophy and Phenomenological Research 20, no. 2 (1959), pp. 231-37.

Nellas, P., Deification in Christ. Orthodox Perspectives on the Nature of the Human Person. (Crestwood: St. Vladimir's Seminary Press, 1997).

Nesteruk, A. V., Light from the East. Theology, Science and the Eastern Orthodox Tradition. (Minneapolis, Fortress Press, 2003).

Nesteruk, A., The Universe as Communion. Towards a Neo-Patristic Synthesis of Theology and Science (London: T\&T Clark, 2008).

Nesteruk, A. V., "Towards Constituting the Identity of the Universe: Apophaticism and Transcendental Delimiters in Cosmology" Journal of Siberian Federal University. Humanities \& Social Sciences 5, n. 3 (2012[1]), pp. 358-94.

Nesteruk, A. V., "Cosmology and Teleology: Purposiveness in the Study of the Universe through the Reading of Kant's Third Critique, Journal of Siberian Federal University. Humanities \& Social Sciences 5, n. 9 (2012[2]), pp. 1304-35.

$$
-467-
$$


Pascal, B., Pensées. Selections, tr. and ed. C. R. Martin Jarret-Kerr (London: SCM Press Ltd, 1959).

Prestige, G. L., God in Patristic Thought (London: SPCK, 1955).

Relton, H. M., A Study of Christology. The Problem of the Relation of the Two Natures in the Person of Christ (London:SPCK, 1917).

Rodzyanko, B. (Bishop), Theory of the Universe's decay and Faith of the Fathers. Capadocian Theology - the Key to Apologetics of Our Time (Moscow, Palomnik, 2003) (in Russian: Родзянко, B., епископ, Теория распада вселенной и вера отцов. Каппадокийское богословие - ключ к апологетике нашего времени. Апологетика XXI века. М.: Паломник, 2003).

Sokolov, S. (Fr.), The Other World and the Time of the Universe. Time and Eternity (Moscow: Kovcheg 2008) (in Russian: Соколов, С., священник, Мир иной и время вселенной. Время и вечность. М.: Ковчег, 2008).

Steinbock, A. J. Home and Beyond.Generative Phenomenology after Husserl (Evanston, Northwestern University Press, 1995).

Ströker, E., Investigarions in Philosophy of Space (Ohio University Press, 1965).

Torrance, T., Space Time and Incarnation (Oxford: Oxford University Press, 1969).

Torrance, T., "The Relation of the Incarnation to Space in Nicene Theology", in The Ecumenical World of Orthodox Civilization, Russia and Orthodoxy, vol. 3, Essays in Honor of Georges Florovsky, (ed. A. Blane and T. E. Bird) (The Hague: Mouton, 1974), pp. $43-70$ (reprinted as ch.10 in T. Torrance, The Divine Meaning: Studies in Patristic Hermeneutics. (Edinburgh: T \& T Clark, 1995), pp. 34373).

Torrance, T., "The Greek Conception of Space in the background of early Christian theology", in The Divine Meaning: Studies in Patristic Hermeneutics (Edinburgh: T \& T Clark, 1995), pp. 289342.

Williams, G. H., “The Neo-Patristic Synthesis of Georges Florovsky”, in A. Blane (ed.) Georges Florovsky. Russian Intellectual and Orthodox Churchman (Crestwood: St. Vladimir's Seminary Press, 1993), pp. 287-340.

Yannaras, C., On the Absence and Unknowability of God (London and New York, T\&T Clark, 2005).

Zenkovsky, V., "The Principles of Orthodox Anthropology", Messenger. Bulletin of the Russian Christian Movement 153 (1988), pp. 5-20; 154 (1988), pp. 67-91 (in Russian: В. В. Зеньковский, Принципы Православной Антропологии//Вестник русского христианского движения т. 153 (1988), с. 5-20; т. 154 (1988), с. 67-91). 


\title{
Вселенная, воплощение и человек: \\ богословие Томаса Торранса \\ и современная космология
}

\author{
А.В. Нестерук \\ Университет Портсмута \\ Лайон Гэйт Бюлдинг, Портсмут \\ РО1 ЗНF, Великобритания
}

В статье проводится философский анализ пространственного парадокса воплощения, являюшегося одной из тем выдаюшегося шотландского богослова ХХ века Томаса Торранса. Парадокс получает интерпретацию в контексте современной космологии, в частности в связи с известным космологическим принципом однородности Вселенной. В качестве дальнейшей разработки богословия Торранса мы анализируем парадокс воплощения для прояснения смысла человеческого состояния, в частности концепџии личности как иентра раскрытия и артикуляции Вселенной.

Ключевые слова: богословие, воплощение, космология, личность, пространство, познаваемость, творение, человечество, Вселенная.

Научная специальность: 09.00.00 - философские науки. 